\title{
Kajian Spasial Kerentanan Airtanah terhadap Pencemaran di Kota Jember dengan Menggunakan Metode SINTACS
}

\author{
Erik Febriarta, Sutanto Trijuni Putro, Ajeng Larasati
}

Masuk: 02032021 / Diterima: 17052021 / Dipublikasi: 30062021

\begin{abstract}
Spatial mapping of groundwater vulnerability to pollution is part of the sustainable management of water resources. The susceptibility of groundwater to pollution can be determined from geological parameters and hydrogeological properties. This study aimed to determine the zone of groundwater vulnerability to pollution in the City of Jember. The method used is multi-criteria modeling by considering the hydrogeological properties of groundwater using the SINTACS method. The parameters used for susceptibility assessment include phreatic/soggiacenza depth (S), infiltration/infiltrazione (I), unsaturated/non-saturated conditions $(N)$, soil texture/typology della copertura $(T)$, aquifer/acquifero media (A), hydraulic conductivity/hydrolic conductivity (C), slope/superficie topografica (S). Each value of each vulnerability parameter is given a weighting factor to obtain a scenario of groundwater vulnerability to pollution. Calculations with weight assessments are required for modeling or scenarios of the impact of pollution. The calculation of the values and weights is obtained from a linear assessment of all variables by producing a vulnerability index value that is then classified against groundwater vulnerability. Based on the results of the study, there are two classes of vulnerability. The level of groundwater vulnerability to pollution is relatively high, with an area of $26 \mathrm{~km} 2(70 \%)$ and a high vulnerability of $11 \mathrm{~km} 2(30 \%)$ of the total area. The dominant factors that influence include phreatic groundwater depth, infiltration rate, and unsaturated zone. In general, the level of groundwater vulnerability to pollution is relatively high.
\end{abstract}

Key words: Groundwater; Pollution; SINTACS; Vulnerability

\begin{abstract}
Abstrak Pemetaan spasial kerentanan airtanah terhadap pencemaran merupakan bagian dari pengelolaan keberlangsungan sumber daya air. Kerentanan airtanah terhadap pencemaran dapat diketahui dari parameter geologi dan sifat hidrogeologi. Tujuan dari penelitian ini adalah mengetahui zona kerentanan airtanah terhadap pencemaran di Kota Jember. Metode yang digunakan adalah pemodelan multi kriteria dengam mempertimbangan sifat hidrogeologi airtanah dengan metode SINTACS. Parameter yang digunakan untuk penilaian kerentanan antara lain Kedalaman freatik/soggiacenza (S), infiltrasi/infiltrazione $(\mathrm{I})$, kondisi tak jenuh/non saturo $(\mathrm{N})$, tekstur tanah/tipologia della copertura $(\mathrm{T})$, media akuifer/acquifero (A), kondivitas hidrolik/hydrolic conductivity (C), kemiringan lereng/superficie topografica (S). Setiap nilai dari masing-masing parameter kerentanan diberi faktor pembobot untuk mendapatkan skenario kerentanan airtanah terhadap pencemaran. Perhitungan dengan penilaian bobot diperlukan untuk pemodelan atau sekenario dampak pencemaran. Perhitungan dari nilai dan bobot diperoleh dari penilaian linier seluruh variabel dengan menghasilkan nilai indeks kerentanan kemudian dikelaskan terhadap tingkat kerentanan airtanah. Berdasarkan hasil penelitian diketahui dua kelas kerentanan. Tingkat kerentanan airtanah terhadap pencemaran agak tinggi dengan luas $26 \mathrm{~km}^{2}(70 \%)$ dan kerentanan tinggi seluas $11 \mathrm{~km}^{2}$ (30\%) dari luas wilayah kota Jember. Faktor yang dominan mempengaruhi antara lain parameter kedalaman freatik airtanah, laju infiltrasi dan zona tak jenuh. Secara umum tingkat kerentanan airtanah terhadap pencemaran agak tinggi.
\end{abstract}

Kata kunci: Airtanah; Pencemaran; SINTACS; Kerentanan

This is an open access article under the CC BY-SA license.

Copyright $(\mathcal{C} 2021$ by Author. Published by Universitas Pendidikan Ganesha.

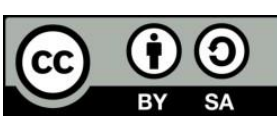




\section{Pendahuluan}

Air merupakan sumber daya alam yang penting bagi kehidupan manusia dan makhluk hidup disekitarnya. Dalam pengelolaan airtanah diperlukan informasi dasar dalam menjaga keberlangsungan sumber daya tersebut. Salah satu isu pengelolaan airtanah adalah potensi pencemaran (Widodo et al., 2015). Dampak dari pencemaran airtanah dapat menurunkan kualitas air yang bedampak pada kesehatan bila dikonsumsi. Pencemaran airtanah dapat dipengaruhi oleh banyaknya aktivitas penggunaan airtanah dan sisa dari aktivitas tersebut tidak dikelola dengan baik, sehingga sumber pencemar (polutan) dapat masuk kedalam sistem akuifer airtanah (Anzaldua et al., 2018; Febriarta \& Riasasi, 2019; Febriarta \& Widyastuti, 2020).

Pencemaran airtanah merupakan kondisi masuknya unsur satuan, komponen fisika atau biologi ke dalam air bawah tanah dan atau berubahnya tatanan air bawah tanah oleh kegiatan manusia atau proses alami yang mengakibatkan mutu air bawah tanah turun sampai ke tingkat tertentu sehingga tidak lagi sesuai dengan peruntukannya (BSN, 2002). Vrba \& Zaporozec (1994) menyebutkan bahwa kerentanan airtanah tidak dapat dilihat secara langsung kondisi dilapangan, hal tersebut dikarenakan faktor yang mempengaruhi berada di dalam tanah. Thapa et al., (2018) juga menyebutkan bahwa konsep

${ }^{1}$ Erik Febriarta, ${ }^{2}$ Sutanto Trijuni Putro, ${ }^{1}$ Ajeng Larasati

${ }^{1}$ Universitas Gadjah Mada, Indonesia

${ }^{2}$ Universitas Negeri Yogyakarta, Indonesia kerentanan airtanah dapat dinilai dari pendekatan multi parameter sifat pembawa air, yaitu faktor kondisi geologi dan sifat hidrogeologi.

Kondisi geologi di Kota Jember tersusun atas Formasi Breksi Argopuro (Qvab) dan Formasi Tuf Argopuro (Qvat). Formasi Breksi Argopuro (Qvab) merupakan bagian dari Gunung Pinggang (2.286 mdpal) yang tersusun atas batuan breksi gunungapi bersusunan andesit, bersisipan lava. Formasi Tuf Argopuro (Qvat) terdapat pada morfologi dataran dengan kemiringan lereng landai hingga curan yang berdapat wilayah Kota Jember. Formasi Tuf Argopuro (Qvat) tersusun atas batuan tuf, tuf sela, tuf abu dan tuf lava yang merupakan bagian dari pengendapan batuan volkanik (Sapei et al., 1992). Kondisi geologi regional Kota Jember disajikan pada Gambar 1.

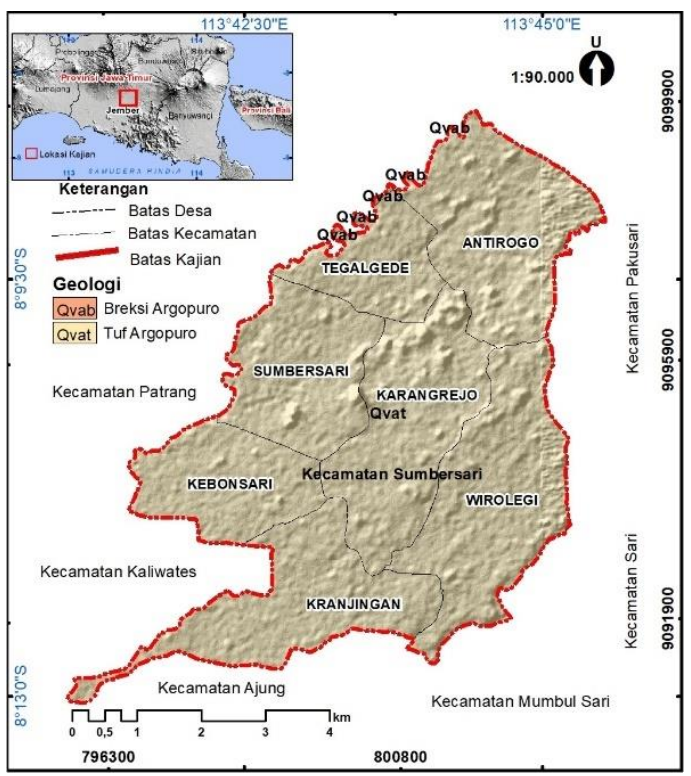

Gambar 1. Geologi Kota Jember didominasi Formasi Tuff Argopuro skala pada 1:90.000

(sumber: Sapei dkk, 1992)

e.febriarta@amail.com 
Kondisi hidrogeologi di Kota Jember berdasarkan sifat produktivitas airtanah terdapat dua karakteristik, yaitu produktivitas tinggi dan produktivitas sedang dengan media ruang antar butir. Media akuifer air rongga antar butir merupakan keterdapatan airtanah dengan sifat air bawah tanah yang bergerak dan berada pada rongga batuan (Febriarta \& Larasati, 2020).

Produktivitas tinggi dengan penyebaran luas, media celah dan antar butir, memiliki keterusan rendah hingga tinggi dengan potensi debit airtanah 5-10 l/detik (KESDM, 2015b). Produktivitas tinggi tersebut merupakan bagian dari endapan volkanik Formasi Breksi Argopuro (Qvab). Produktivitas tinggi dengan penyebaran luas pada media litologi akuifer ruang antar butir, memiliki keterusan sedang hingga tinggi, dengan potensi debit $>10 \mathrm{l} /$ detik terdapat pada bagian barat, termasuk Desa Kebon sari dan sebagian Desa Kranjingan (Gambar 2).

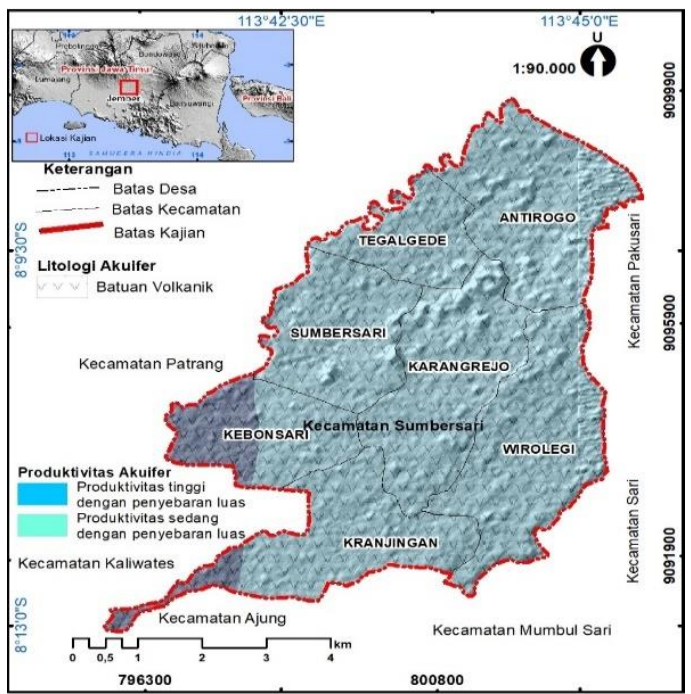

Gambar 2. Kondisi hidrogeologi Kota Jember termasuk produktivitas sedang pada skala 1:90.000.

(Sumber: KESDM, 2015b)
Produktivitas sedang dengan penyebaran luas, terdapat di wilayah perkotaan Kota Jember dengan media akuifer ruang antar butir, dengan sifat keterusan sedang dan potensi debit 5$10 \mathrm{l} /$ detik (KESDM, 2015a). Kondisi produktivitas tinggi mempunyai potensi airtanah yang besar tetapi menurut (Todd \& Mays, 2005) mempunyai potensi pencemaran dikarenakan cepat dalam mengalirkan airtanah yang tercemar (sumber polutan) dengan cepat masuk kedalam sistem akuifer. Hal tersebut dipengaruhi juga oleh kondisi batuan yang porus (Elsayed et al., 2020). Kedua karakteristik produktivitas airtanah tersebut termasuk bagian dari endapan volkanik dari Formasi Tuf Argopuro (Qvat) (Sapei dkk, 1992).

Keterdapatan airtanah pada endapan volkanik memiliki potensi airtanah yang tinggi baik secara kuantitas dan kualitas airtanah. Kondisi morfologi pada dataran lereng bawah dengan kemiringan lereng landai hingga miring, secara sifat pergerakan airtanah, termasuk bagian lepasan airtanah (KESDM, 2015b). Daerah lepasan airtanah merupakan daerah atau tempat terjadinya pelepasan (groundwater discharge) atau pengaliran dari tempat cadangan airtanah dari batuan yang terjadi secara alamiah (BSN, 2005). Daerah wilayah perkotaan Kota Jember termasuk bagian dari Cekungan airtanah (CAT) Jember - Lumajang yang termasuk kelulusan airtanah lintas kabupaten atau kota (KESDM, 2018; RI, 2017). Putranto et al., 2020 juga menyebutkan bahwa daerah yang berada pada CAT mempunyai kecenderungan kerentanan airtanah yang tinggi. 
Parameter akuifer dengan nilai kelulusan airtanah tinggi mempunyai korelasi dengan kondisi debit airtanah yang tinggi (Todd \& Mays, 2005; Wicaksono dkk, 2020). Karakteristik litologi akuifer dengan kelulusan yang tinggi, seperti pada formasi batuan endapan volkanik memiliki produktivitas air yang tinggi, kedalaman tinggi muka air (akuifer) yang relatif dangkal dan mempunyai kemampuan mengisi akuier dengan cepat atau waktu pulih kembali ke kondisi semula relatif cepat (Todd \& Mays, 2005). Berdasarkan sifat aliran yang relatif cepat, sifat batuan yang porus dan kondisi freatik yang dangkal tersebut, memiliki permasalahan lingkungan terkait potensi pencemaran pada airtanah (sumber daya air) (Purnama \& Cahyadi, 2019; Putranto \& Rüde, 2016; Vienastra \& Febriarta, 2020).

Pemetaan kerentanan airtanah merupakan langkah strategis dalam perlindungan dan pengelolaan lingkungan hidup berkelanjutan (Febriarta dkk., 2020; MEA, 2005; Raju Thapa et al., 2019). Kerentanan airtanah terhadap pencemaran dapat diperoleh dari penilaian faktor yang mempengaruhi pencemaran seperti infiltrasi, kedalaman airtanah dan kemiringan lereng (topografi) (Li et al., 2018). Penilaian kerentanan airtanah dapat juga diketahui dari sifat efektivitas batuan dengan kondisi keterbatasan data (Putranto et al., 2020; Vienastra \& Febriarta dkk, 2020). Kedua metode tersebut belum mempertimbangkan sifat hidrogeologi berupa media akuifer, dan kondisi aerasi batuan dimana varabel tersebut dapat mempercepat laju pencemaran. Oleh karena itu maka tujuan dari penelitian ini adalah mengetahui indeks kerentanan airtanah terhadap pencemaran dengan multi kriteria terhadap sifat efektivitas dan sifat hidrogeologi pada batuan endapan volkanik di wilayah perkotaan Kota Jember.

\section{Metode}

Lokasi kajian kerentanan airtanah terhadap pencemaran, secara geografis berada di $-8.150005^{\circ} \mathrm{LU}$ hingga $-8.251017^{\circ} \mathrm{LU}$ dan $113.612012^{\circ}$ BT hingga $113.757036^{\circ} \mathrm{BT}$, lokasi tersebut secara administrasi berada di wilayah Kecamatan Sumbersari, Kabupaten Jember, Provinsi Jawa Timur. Luas Kecamatan Sumbersari seluas $36,61 \quad \mathrm{~km}^{2}$. Kecamatan Sumbersari terdapat tujuh (7) desa, yaitu Desa Kranjingan $\left(5,68 \mathrm{~km}^{2}\right)$, Desa Wirolegi $\left(6,90 \mathrm{~km}^{2}\right)$, Desa Karangrejo $\left(6,17 \mathrm{~km}^{2}\right)$, Desa Kebonsari $\left(3,95 \mathrm{~km}^{2}\right)$, Desa Sumbersari $\left(4,74 \mathrm{~km}^{2}\right)$, Desa Tegalgede $\left(5,68 \mathrm{~km}^{2}\right)$, dan Desa Antirogo (6,32 km²) (BIG, 2018b; BPS Kabupaten Jember, 2019). Batas sebelah utara berbatasan dengan Kecamatan Patrang dan Kecamatan Arjasa, batas barat berbatasan dengan Kecamatan Patrang dan Kaliwates, batas timur berbatasan dengan Kecamatan Pakusari dan Mayang, batas selatan berbatasan dengan Kecamatan Ajung dang Mumbulsari (Gambar 1).

$$
\text { Dalam penelitian ini }
$$

menggunakan data primer (pengukuran langsung di lapangan) dan menggunakan data sekunder. Data primer yang untuk penilaian kerentanan airtanah, yaitu: 1) kedalaman freatik muka airtanah $(\mathrm{m}), 2$ ) tekstur tanah, dan 3) kondisi kemiringan lereng. 
Kondisi kedalaman freatik muka airtanah diperoleh dari pengukuran kedalaman tinggi muka air $(\mathrm{m})$ dengan menggunakan pita ukur dari permukaan tanah hingga muka airtanah, tekstur tanah diperoleh dari pengamatan dan uji tekstur, kondisi kemiringan lereng diperoleh dengan instrumen ukur slope rangefinder dengan satuan pengukuran kemiringan lereng dalam persen (\%).

Data sekunder yang digunakan untuk penilaian, yaitu 1) nilai infiltrasi (mm/jam) diperoleh dari korelasi data tekstur tanah terhadap laju infiltrasi menggunakan persamaan dari Asdak, (2002), 2) kondisi aerasi pada batuan atau zona tak jenuh diperoleh dari interpretasi tekstur tanah dan hasil geolistrik Priyono \& Rizal (2013) dan data litologi akuifer dari KESDM (2015a), dan 3) nilai konduktivitas hidraulik atau kelulusan airtanah (m/detik) diperoleh interpretasi geolistrik Priyono \& Rizal (2013), data litologi akuifer dari (KESDM, 2015b) kemudian dikorelasikan sifat kelulusan batuan dari persamaan Todd \& Mays (2005) dan Fetter (2014), dan 4) data parameter media (litologi) akuifer diperoleh dari pengukuran geolistrik Priyono \& Rizal (2013). Sumber data yang digunakan disajikan pada Tabel 1 , sebagai berikut.

Table 1. Sumber data penilaian kerentanan metode SINTACS

\begin{tabular}{|c|c|c|}
\hline Parameter & Data & Sumber Data \\
\hline (S) Soggiacenza (Depth of phreatic) & Kedalaman muka air & Priyono dan Rizal, 2013 \\
\hline (I) Infiltrazione (Infiltration) & Infiltras (mm/jam) & $\begin{array}{l}\text { KESDM, 2012; Priyono } \\
\text { dan Rizal, } 2013\end{array}$ \\
\hline (N) Non Saturo (Aeration Condition) & $\begin{array}{l}\text { Kondisi aerasi pada } \\
\text { batuan }\end{array}$ & KESDM, 2015a,b; \\
\hline $\begin{array}{l}\text { (T) Tipologia Della Copertura (Soil } \\
\text { Texture) }\end{array}$ & Tekstur tanah & $\begin{array}{l}\text { Priyono dan Rizal, 2013; } \\
\text { Sisultan, 2017; }\end{array}$ \\
\hline (A) Acquifero (Aquifer media) & Media (litologi) akuifer & $\begin{array}{l}\text { KESDM, 2015a; Priyono } \\
\text { dan Rizal, 2013; Sapei } \\
\text { dkk. } 1992\end{array}$ \\
\hline (C) Conducibilita (hydrolic conductivity) & $\begin{array}{l}\text { Konduktivitas hidraulik } \\
\text { (K)/kelulusan (m/detik) }\end{array}$ & $\begin{array}{l}\text { KESDM, 2012; Priyono } \\
\text { dan Rizal, } 2013\end{array}$ \\
\hline $\begin{array}{l}\text { (S) Superficie topografica (topography } \\
\text { slope) }\end{array}$ & Kemiringan lereng (\%) & $\begin{array}{l}\text { BIG, 2018a; Priyono dan } \\
\text { Rizal, } 2013\end{array}$ \\
\hline
\end{tabular}

\section{Penilaian dan Pembobotan Metode SINTACS}

Pendekatan untuk mengetahui kerentanan airtanah terhadap pencemaran menggunakan penilaian dan pembobotan SINTACS yang dilakukan dalam beberapa tahapan, seperti yang disajikan dalam diagram alir pada Gambar 3.

Identifikasi setiap kelas

parameter dari data primer dan data sekunder, penilaian setiap kelas parameter, kemudian untuk merepresentasikan hasil kerentanan yang relefan di lapangan digunakan pembobotan. Tahapan analisis secara keruangan (spasial) dengan mengkelaskan tingkat indeks kerentanan (Febriarta \& Wibowo, 2021; Purnama dan Cahyadi, 2020). 


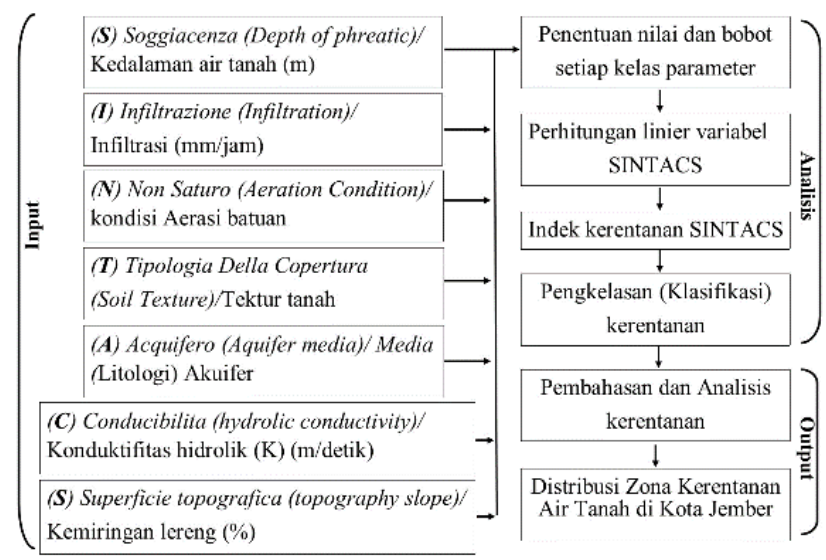

Gambar 3. Diagram alir penelitian kerentanan airtanah

$\begin{array}{lcr}\text { Metode } & \text { SINTACS } & \text { merupakan } \\ \text { pendekatan } & \text { numberik } & \text { dengan } \\ \text { menggunakan } & \text { parameter } & \text { (S) }\end{array}$

soggiacenza (depth of phreatic)/ kedalaman freatik muka airtanah $(\mathrm{m})$, (I) infiltrazione (infiltration)/ laju infiltrasi (mm/jam), (N) non saturo (aeration condition)/ kondisi areasi pada batuan, (t) tipologia della copertura (soil texture)/ tekstur tanah, (A) acquifero (aquifer media)/ litologi akuifer, (c) conducibilita (hydrolic conductivity)/nilai kelulusan (m/detik), (S) superficie topografica (topography slope)/ kemiringan lereng (\%) (Civita, 1994; Civita \& De Maio, 2004; Gunawan dkk., 2013; Linggasari et al., 2019; Purnama \& Cahyadi, 2019). Penilaian setiap kelas dan pembobotan dari parameter kerentanan SINTACS disajikan pada Tabel 2.

Pembobotan setiap parameter untuk menghasilkan skenario yang dapat mengambarkan kondisi di lapangan, disajikan pada Tabel 3. Dari hasil penilaian dan pembobotan dilakukan perhitungan variable linier ketujuh parameter, menghasilkan nilai indeks kerentanan. Nilai indeks kerentanan SINTACS mengunakan persamaan rumus (Civita \& De Maio, 2004) sebagai berikut :

Indeks kerentanan $=\mathrm{SrSw}+\mathrm{Irlw}+$ $\mathrm{NrNw}+\mathrm{TrTw}+\mathrm{ArAw}+\mathrm{CrCw}+\mathrm{SrSw}$ (1)

dimana :

$r$ (rating): nilai masing-masing parameter (Tabel 2)

w (weight): bobot untuk masing-masing parameter (Tabel 3).

Table 3. Skenario bobot SINTACS

\begin{tabular}{|c|c|c|c|c|c|c|c|}
\hline Skenario Bobot & $\mathbf{S}$ & I & $\mathbf{N}$ & $T$ & $\mathbf{A}$ & C & $\mathbf{S}$ \\
\hline Dampak normal & 5 & 4 & 5 & 3 & 3 & 3 & 3 \\
\hline Dampak relevan & 5 & 5 & 4 & 5 & 3 & 2 & 2 \\
\hline Drainase & & & & & & & \\
\hline $\begin{array}{l}\text { permukaan } \\
\text { (rembesan) }\end{array}$ & 4 & 4 & 4 & 2 & 5 & 5 & 2 \\
\hline Karst & 2 & 5 & 1 & 3 & 5 & 5 & 5 \\
\hline $\begin{array}{l}\text { Formasi batuan } \\
\text { bercelah }\end{array}$ & 4 & 4 & 4 & 4 & 4 & 5 & 4 \\
\hline Nitrat & 5 & 5 & 4 & 5 & 2 & 2 & 3 \\
\hline
\end{tabular}

Analisis secara keruangan (spasial) kerentanan airtanah terhadap pencemaran dengan pendekatan SINTACS menggunakan Sistem Informasi Geografi (SIG). Pengkelasan tingkat kerentanan airtanah terhadap 
Tabel 2. Penilaian setiap kelas parameter SINTACS

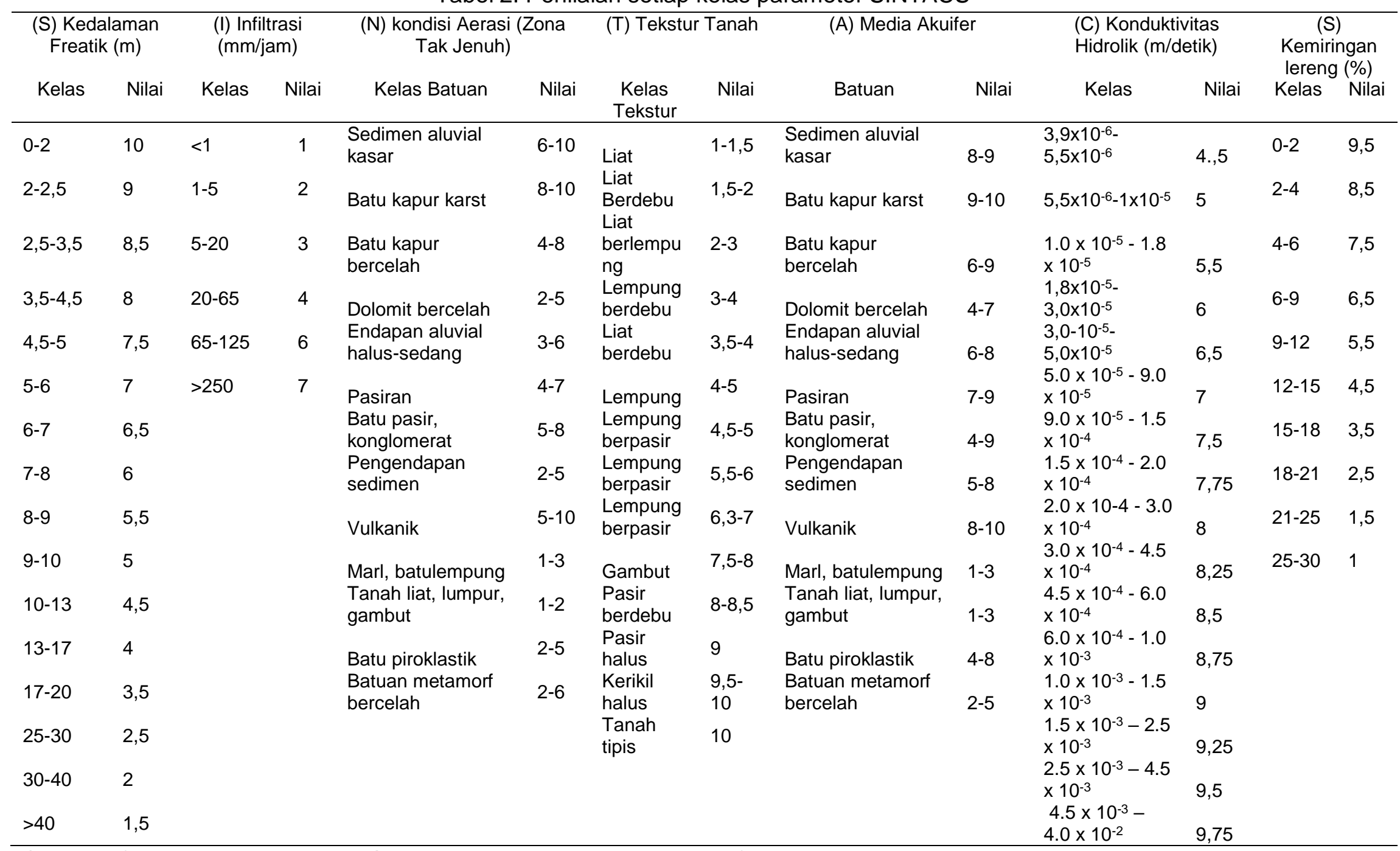

Sumber: Civita \& De Maio, 2004; Gunawan dkk, 2013; Purnama dan Cahyadi, 2020 
pencemaran diperoleh dari pengelompokan rentang nilai indeks kerentanan (rumus 1). Kriteria atau rentang tingkat kerentanan airtanah terhadap pencemaran disajikan pada Tabel 4.

Table 4. Kriteria tingkat kerentanan SINTACS

\begin{tabular}{lc}
\hline \multicolumn{1}{c}{ Tingkat } & Interval Indeks \\
Kerentanan & SINTAC \\
\hline Sangat Rendah & $<80$ \\
Rendah & $80-104$ \\
Sedang & $105-139$ \\
Agak Tinggi & $140-185$ \\
Tinggi & $186-210$ \\
Sangat Tinggi & $>210$ \\
\hline
\end{tabular}

Sumber: Civita, and De Maio, 2004

3. Hasil dan Pembahasan

\section{Karakteristik Airtanah Terhadap Kerentanan}

Soggiacenza (depth of phreatic)

(S) merupakan parameter dengan nilai kedalaman freatik muka airtanah. Kondisi dinamika kedalaman muka airtanah diperoleh dari Priyono \& Rizal (2013) kemudian diperbaharui dengan pengukuran di lapangan. Lokasi pengukuran lapangan disajikan pada Gambar 4a. Secara umum bagian timur nilai kedalaman airtanah semakin dangkal yang merupakan bagian dari lereng kaki bagian bawah dengan kemiringan lereng yang semakin melandai. Kondisi topografi tersebut membentuk daerah yang relatif datar dan menjadi tempat berkumpulnya airtanah. Pada daerah dengan kondisi kedalaman airtanah yang dangkal memiliki keuntungan dalam memperoleh airtanah tetapi mempunyai faktor yang mendorong terjadinya kerentanan airtanah, dimana bila terdapat sumber polutan dipermukaan tanah, dapat meresap dan turun ke sistem akuifer dengan jarak yang relatif pendek.

Berdasarkan hasil pengukuruan diperoleh nilai kedalaman dengan rentang 4,5 - 7,2 $\mathrm{m}$ dibawah permukaan tanah. Kedudukan tinggi muka airtanah berada pada material batuan berupa pasir halus hingga sedang (Priyono \& Rizal, 2013). Hasil penilaian faktor kerentanan airtanah dari kondisi freatik disajikan pada Tabel 5. Kedalaman 7 - $8 \mathrm{~m}$ berada di bagian timur daerah penelitian meliputi sebagian Desa Antirogo, sebagian Desa Tegalrejo dan

Desa Wirolegi memiliki nilai kerentanan 6. Kedalaman airtanah 6-7 $\mathrm{m}$ dibawah permukaan tanah berada pada bagian tengah memiliki nilai kerentanan 6,5 dan kedalaman 4,5-6 m terdapat di bagian barat meliputi Desa kebonsari, Desa Kranjingan, sebagian desa karangrejo dan Desa Sumbersari memiliki nilai kerentanan 7-7,5.

Tabel 5. Kondisi freatik muka airtanah

\begin{tabular}{clll}
\hline Kedalaman muka airtanah (m) & Nilai & Bobot & Total \\
\hline 4,9 & 7,5 & 5 & 37,5 \\
5,3 & 7 & 5 & 35 \\
6,5 & 6,5 & 5 & 32,5 \\
7,2 & 6 & 5 & 30 \\
\hline
\end{tabular}

Sumber: Analisis data, 2021 
Infiltrazione (infiltration) (I) atau kondisi infiltrasi merupakan peristiwa meresapnya airtanah secara horisontal yang dipengaruhi oleh gravitasi dengan satuan mm/jam (Singhal \& Gupta, 2010). Laju infiltrasi diperoleh dari persamaan dari pengukuran tekstur tanah dilapangan. Penilaian laju infiltrasi diperoleh dari korelasi tekstur tanah permukaan dengan persamaan dari Todd \& Mays (2005).

Kondisi infiltrasi dalam kerentanan pencemaran adalah apabila tingkat kemampuan tanah dalam meloloskan air yang masuk kedalam tanah tinggi, maka mempercepat pergerakan sumber pencemar (polutan) masuk ke sistem akuifer tanah. Sedangkan bila kondisi tingkat kemampuan tanah dalam meloloskan air yang masuk ke dalam tanah rendah, maka sumber (suplay) air di permukaan menjadi besar yang mengakibatkan akumulasi di permukaan tanah menjadi genangan dan menjadi air limpasan (runoff). Berdasarkan pengukuran uji tekstur permukaan tanah diketahui tiga (3) kondisi yaitu pada tekstur lempung berpasir dengan kondisi laju infiltrasi 15 $\mathrm{mm} / \mathrm{jam}$, pasir halus dengan laju infiltrasi $30 \mathrm{~mm} / \mathrm{jam}$ yang terdapat di daerah aliran sungai dan sepadan sungai (Gambar 4b) dan pasir kasar dengan laju infiltrasi $67 \mathrm{~mm} / \mathrm{jam}$ yang terdistribusi secara umum merata di wilayah penelitian. Kondisi laju infiltrasi akan menjadi dengan cepat bila berada pada kondisi akuifer permeabilitas tinggi yang dipengruhi oleh sifat pori batuan. Seperti pada kondisi pasir halus-kasar memiliki nilai kerentanan 46 (Tabel 6) yang termasuk dalam kelas tinggi, kondisi tersbut dipengaruhi oleh tekstur pasir yang sedikit menahan air dan terjadi perkolasi

Tabel 6. Kondisi infiltrasi

\begin{tabular}{lllll}
\hline \multicolumn{1}{c}{ Tekstur tanah } & Infitrasi (mm/jam) & Nilai & Bobot & Total \\
\hline Lempung berpasir & 15 & 3 & 4 & 12 \\
Pasir halus & 30 & 4 & 4 & 16 \\
Pasir kasar & 67 & 6 & 4 & 24 \\
\hline
\end{tabular}

Sumber: Analisis data, 2021

Non saturo (aeration condition) $(\mathrm{N}) /$ kondisi aerasi pada batuan atau kondisi tak jenuh merupakan parameter akuifer dari media ukuran antar butir. Data kondisi aerasi pada batuan atau kondisi tak jenuh diperoleh dari Sisultan (2017) untuk tekstur tanah permukaan kemudian diperbaharui dengan pengukuran lapangan dan data litologi didalam tanah diperoleh dari kondisi litologi akuifer mengacu KESDM (2015a). Distribusi zona aerasi pada batuan atau zona tak jenuh disajikan pada Tabel 7 dan Gambar 4c.

Tabel 7. Kondisi aerasi pada batuan

\begin{tabular}{lllll}
\hline \multicolumn{1}{c}{ Formasi } & Penyusun batuan & Nilai & Bobot & Total \\
\hline Breksi Argopuro (Qvat) & Tuf & 7 & 5 & 35 \\
Formasi Tuf Argopuro (Qvab) & Breksi gunungapi, & 5 & 5 & 25 \\
\hline
\end{tabular}

Sumber: Analisis data, 2021 
Priyono \& Rizal (2013) menyebutkan bahwa di wilayah penelitian didominasi oleh penysusn material pasir sedang-kasar,tuff yang merupakan pengendapan batuan volkanik dari Formasi Tuf Argopuro (Qvat). Berdasakan kondisi tersebut terdapat dua (2) penialian kerentanan pada penyusun batuan breksi lava (Qvab) memiliki tingkat kerentanan 5 sedangkan pada penysusun batuan pasir kasar dan tuf memiliki nilai tingkat kerentanan yang lebih tinggi dengan nilai 7.

Tipologia della copertura (soil texture) ( $\mathrm{T}$ ) atau kondisi tekstur tanah merupakan parameter kerentanan dari sifat kerapatan material penyusun, sehingga mempengaruhi penyebaran peresapan sumber pencemar (polutan) dipermukaan. Tekstur tanah diperoleh dari peta tanah Provinsi Jawa Timur pada skala 1:50.000 dari Kementerian Pertanian mengacu Sisultan (2017) dan pembaharuan dil apangan dengan pengujian tekstur tanah.

Berdasarkan hasil pengamatan dan pengujuan tekstur tanah, diketahui bahwa batu induk pembentuk tanah berasal dari rombakan endapan volkanik. Tekstur tanah lempungan memiliki tingkat kerentanan yang rendah, hal tersebut dipengauhi oleh sifat impermeabel yang memperlambat hingga menahan pergerakan air masuk kedalam tanah (Febriarta dkk, 2020; Purnama dkk., 2013). Pada kondisi tekstur lempung berpasir halus memiliki nilai 4,5 terhadap kerentanan pencemaran, lempung berpasir sedang mempunyai tingkat kerentanan 5 dan lempung berpasir kasar mempunyai tingkat kerentanan 6 . Sedangkan pada tektur endapan dengan struktur lepaslepas seperti pasir sedang-kasar halus memiliki nilai kerentanan 8 , tekstur pasir sedang memiliki nilai 8,5 dan pada tekstur pasir kasar memiliki nilai tinggi, yaitu 9. Penilaian dan pemberian bobot skenario normal disajikan pada Tabel 8. Distribusi tekstur tanah di daerah penelitian disajikan pada Gambar 4d. Tekstur pasir mempunyai potensi kerentanan airtanah terhadap pencemaran lebih tinggi dibandingkan dengan tektur lempung dikarenakan sifat media pori yang cepat mengalirkan air (Mepaiyeda et al., 2020).

Tabel 8. Kondisi tekstur tanah permukaan

\begin{tabular}{llll}
\hline Tekstur tanah & Nilai & Bobot & Total \\
\hline Lempung berpasir halus & 4,5 & 3 & 13,5 \\
Lempung berpasir sedang & 5 & 3 & 15 \\
Lempung berpasir kasar & 6 & 3 & 18 \\
Pasir halus & 8 & 3 & 24 \\
Pasir sedang & 8,5 & 3 & 25,5 \\
Pasir kasar & 9 & 3 & 27 \\
\hline
\end{tabular}

Sumber: Analisis data, 2021

Acquifero (aquifer media) (A)/ media (litologi) akuifer merupakan formasi geologi penyusun batuan atau lapisan batuan jenuh air di bawah permukaan tanah yang dapat dan menyimpan dan meneruskan air
(Bastani \& Harter, 2020; BSN, 2005). Penilaian media akuifer dipoeroleh dari pengukuran geolistrik Priyono \& Rizal (2013). Secara umum penyusun batuan adalah endapan volkanik, yaitu batu breksi, pasir halus-kasar, dan tuf. 
Keterdapatan airtanah diketahui berada pada penyusun batuan pasir halus hingga kasar. Potensi airtanah tanah terdapat pada material batuan dengan media pori seperti pasiran (Sugianti et al., 2016). Litologi akuifer keterdapatan airtanah terdistribusi merata secara mendominasi di daerah penelitian, seperti yang disajikan pada Gambar 4e. Berdasarkan penysusun litologi akuifer tersebut diketahui nilai kerentanan airtanah terhadap pencemaran adalah 8, seperti yang disajikan pada Tabel 9.

Tabel 9. Media (litologi) akuifer

\begin{tabular}{lllll}
\hline \multicolumn{1}{c}{ Formasi } & Penyusun batuan & Nilai & Bobot & Total \\
\hline Breksi Argopuro (Qvat) & Tuf & 8 & 3 & 24 \\
Formasi Tuf Argopuro (Qvab) & Breksi gunungapi & 8 & 3 & 24 \\
\hline
\end{tabular}

Sumber: Analisis data, 2021

\section{Conducibilita (hydrolic}

conductivity) (C) atau konduktivitas hidraulik merupakan nilai yang menunjukkan kemampuan batuan dalam meluluskan air di dalam ronggarongga batuan dengan satuan $\mathrm{m} /$ detik (Thapa et al., 2018). Nilai konduktivitas hidraulik atau kelulusan (K) diperoleh dari pengukuran Priyono \& Rizal (2013). Diketahui bahwa nilai konduktivitas atau nilai kelulusan (K) pada penysusun batuan breksi bagian dari Formasi Formasi Tuf Argopuro (Qvab) adalah $70 \mathrm{~m} /$ detik yang terdapat di bagian barat daerah penelitian, sedangkan pada Formasi Breksi Argopuro (Qvat) adalah 73,9 m/detik.
Rentang nilai kelulusan airtanah tersebut memiliki nilai kerentanan terhadap pencemaran pada kelas yang sama yaitu 8,75 . Hasil penilaian dan pembobotan nilai konduktivitas hidraulik atau kelulusan (K) airtanah disajikan pada Tabel 10 dan distribusi keruangan (spasial) disajikan pada Gambar 4f. Berdasarkan nilai kelulusan $(\mathrm{K})$ dengan rentang 70-73,9 m/detik, termasuk kedalam kelas tinggi dalam pergerakan air, hal tersebut dipengaruhi oleh material dengan struktur lepas-lepas dan media rongga antar butir dengan sifat kelulusan air yang tinggi (AnimGyampo et al., 2019; Wicaksono dkk, 2020).

Tabel 10. Nilai konduktivitas hidraulik

\begin{tabular}{llllll}
\hline \multicolumn{1}{c}{ Formasi } & Penyusun batuan & $\begin{array}{c}\text { Kelulusan } \\
(\mathbf{m} / \text { detik) }\end{array}$ & Nilai & Bobot & Total \\
\hline Breksi Argopuro (Qvat) & Tuf & 73,9 & 8,75 & 3 & 26,25 \\
Formasi Tuf Argopuro (Qvab) & Breksi gunungapi & 70 & 8,75 & 3 & 26,25 \\
\hline
\end{tabular}

Sumber: Analisis data, 2021

Superficie topografica

(topography slope) (S)/ kemiringan lereng merupkan kondisi fisik kelerengan yang mempengaruhi pergerakan airtanah di permukaan (Putranto dkk, 2019). Kondisi kemiringan lereng (slope) diperoleh dari ekstrasi data digital elevasi model (DEM) dari BIG, (2018). Data yang digunakan adalah seamless digital elevation model nasional (DEMNas) dengan resolusi $30 \mathrm{~m}$. Digital elevasi model (DEM) tersebut dikonversi menjadi kemiringan lereng dalam 
persen (\%) dengan system informasi geografis (SIG). Berdasarkan perhitungan diketahui sepuluh (10) kelas kemiringan lereng. Penilaian kelas kemiringan lereng datar (0-2\%) adalah 9,5 atau memiliki kerentanan tertinggi dibandingkan dengan kondisi kemiringan lereng sangat curam-terjal (>25\%) adalah dengan nilai 1 , nilai terendah atau paling tidak mempengaruhi.

Hasil penilaian dan pembobotan parameter kerentanan airtanah terhadap pencemaran disajikan pada Tabel 11 dan secara keruangan (spasial) disajikan pada Gambar 4g. Kondisi kemiringan yang semakin curan akan memiliki potensi kerentanan yang relatif rendah dikarenakan pada kemiringan yang curam, aliran permukaan (runoff) berpindah dan mengalir secara gravitasi tidak tergenang (Gambar 5). Sedangkan pada kondisi kemiringan lereng yang landai hingga datar dan membentuk cekungan mempunyai potensi kerentanan pencemaran sumber pencemar (polutan) lebih tinggi, yang diakibatkan oleh kondisi topografi yang dapat mengumpulkan genangan pada lokasi tertentu dan jika genangan tersbut tercemar maka secara berulang dapat masuk meresap kedalam tanah dan mencemari sistem akuifer airtanah (Febriarta, dkk, 2020; Purnama \& Cahyadi, 2019).

\begin{tabular}{cccc}
\multicolumn{4}{c}{ Tabel 11. Kondisi kemiringan lereng } \\
\hline $\begin{array}{c}\text { Kemiringan } \\
\text { lereng }(\%)\end{array}$ & Nilai & Bobot & Total \\
\hline $25-30$ & 1 & 3 & 3 \\
$21-25$ & 1,5 & 3 & 4,5 \\
$18-21$ & 2,5 & 3 & 7,5 \\
$15-18$ & 3,5 & 3 & 10,5 \\
$12-15$ & 4,5 & 3 & 13,5 \\
$9-12$ & 5,5 & 3 & 16,5 \\
$6-9$ & 6,5 & 3 & 19,5 \\
$4-6$ & 7,5 & 3 & 22,5 \\
$2-4$ & 8,5 & 3 & 25,5 \\
$0-2$ & 9,5 & 3 & 28,5 \\
\hline
\end{tabular}

Sumber: Analisis data, 2021

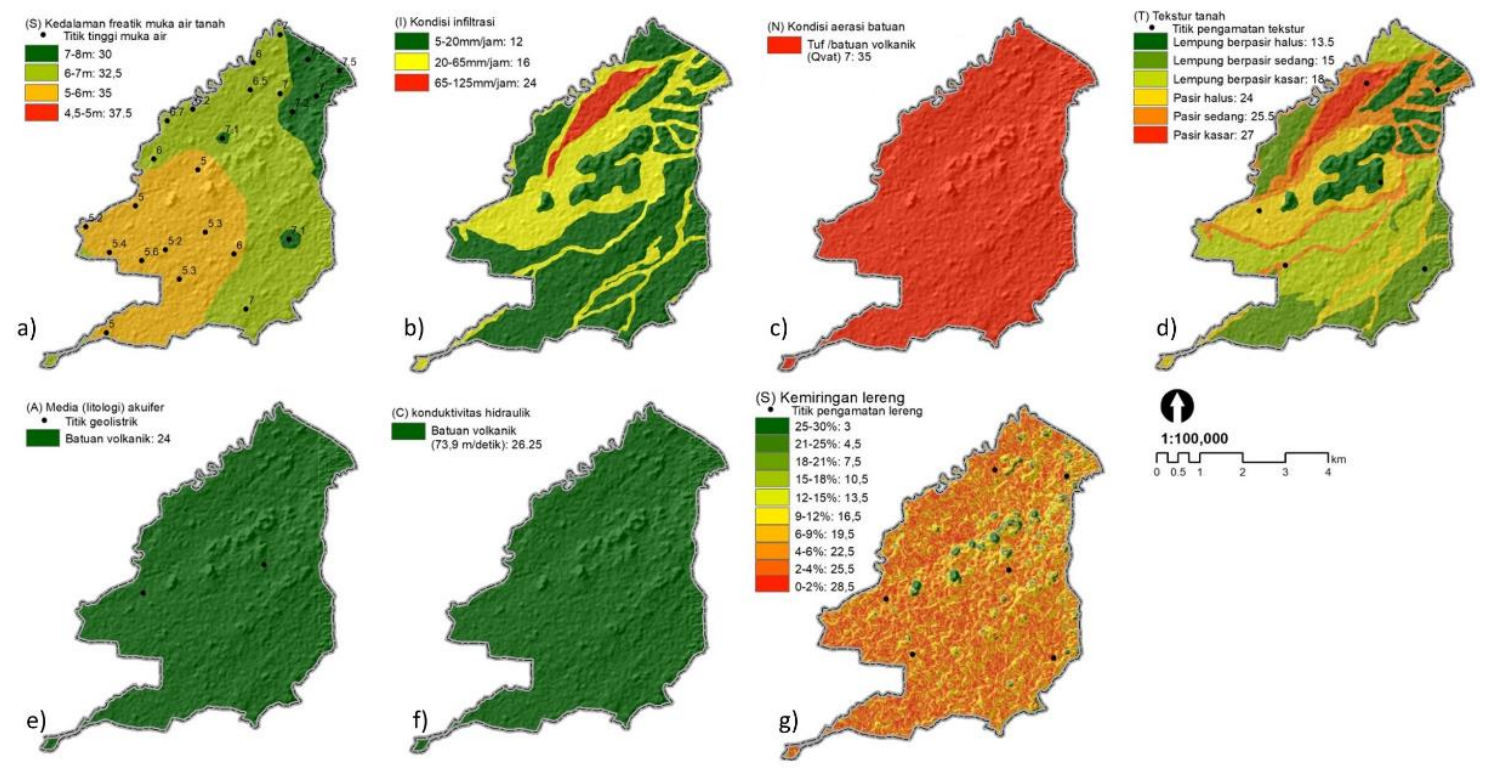

Gambar 4. Distribusi nilai total sekenario (pembobotan) normal setiap parameter 


\section{Analisis Tingkat Kerentanan SINTACS}

Dari perhitungan nilai (rating) dan bobot (weight) kerentanan airtanah terhadap pencemaran diperoleh dari nilai indeks (rumus 1). Pemodelan skenario (pembobotan) menggunakan kondisi normal. Nilai indeks kerentanan SINTACS memiliki rentang 145,25 199,75. Kelas tersebut masuk pada kelas kerentanan agak tinggi (140-185) dan tinggi (186-199).

Kerentanan airtanah terhadap pencemaran agak tinggi memiliki karakteristik kerentanan airtanah terhadap pencemaran agak tinggi memiliki kondisi freatik kedalaman muka airtanah 6,5 -7,2 m di bawah permukaan tanah, kondisi laju infiltrasi 15-30 mm/jam, kondisi zona tak jenuh air pasir halus dan tuf, kondisi tekstur tanah permukaan lempungan, media (litologi) akuifer berupa endapan volkanik pasir sedang, nilai konduktivitas hidraulik atau laju kelulusan (K) air $70 \mathrm{~m} /$ detik dan memiliki kenampakan kemiringan lereng (slope) miring (12\%) hingga curam $(>30 \%)$. Sedangkan karaktersitik kerentanan airtanah terhadap pencemaran tinggi, memiliki kondisi dinamika freatik kedalaman muka airtanah 4,9-5,3 m dibawah permukaan tanah, laju infiltrasi sebesar $67 \mathrm{~mm} / \mathrm{jam}$, memiliki zona aerasi pada batuan atau kondisi tak jenuh berupa pasir sedangkasar, kondisi tekstur tanah berupa pasiran dengan struktur lepas-lepas, media (litologi) akuifer berupa pasir sedang-kasar dan tuf, nilai konduktivitas hidraulik atau laju kelulusan (K) 73,9 m/detik dan kondisi kemiringan lereng agak miring $(9 \%)$ hingga datar $(0-2 \%)$.

Berdasarkan luas zona kerentanan airtanah terhadap pencemaran agak tinggi seluas $26 \mathrm{~km}^{2}$ atau $70 \%$ dan kerentanan agak tinggi seluas $11 \mathrm{~km}^{2}$ atau $30 \%$ dari luas wilayah Kecamatan Sumbersari (Gambar 5). Luas wilayah pada zona kerenatanan agak tinggi terendah di sebagian Desa Tegalgede dan terluas pada Sebagian desa Wirolegi. Sedangkan kerentanan tinggi terendah terdapat di Sebagian Desa Wirolegi dan terluas berada di Sebagian Desa Sumbersari yang merupakan pusat perkotaan di Kota Jember. Luas zona kerentanan perwilayah disajikan pada Tabel 11.

Tabel 11. Luas zona kerentanan airtanah terhadap pencemaran

\begin{tabular}{|c|c|c|c|c|c|}
\hline \multirow{2}{*}{\multicolumn{2}{|c|}{ Desa }} & \multicolumn{2}{|c|}{ Agak Tinggi } & \multicolumn{2}{|c|}{ Tinggi } \\
\hline & & \multirow{2}{*}{$\frac{\mathrm{km}^{2}}{4,8}$} & \multirow{2}{*}{$\frac{\%}{13}$} & \multirow{2}{*}{$\begin{array}{l}\mathrm{km}^{2} \\
0,9\end{array}$} & \multirow{2}{*}{$\begin{array}{c}\% \\
2,5\end{array}$} \\
\hline 1 & Kranjingan & & & & \\
\hline \multirow{2}{*}{$\begin{array}{l}2 \\
3\end{array}$} & & 6,0 & 16,4 & 0,9 & 2,4 \\
\hline & Karangrejo & 4,9 & 13,3 & 1,3 & 3,6 \\
\hline 4 & Kebonsari & 2 & 5,5 & 1,9 & 5,3 \\
\hline 5 & Sumbersari & 2,2 & 5,9 & 2,6 & 7 \\
\hline 6 & Tegalgede & 1,1 & 2,9 & 1,8 & 4,9 \\
\hline \multirow[t]{2}{*}{7} & Antirogo & 4,7 & 12,7 & 1,7 & 4,6 \\
\hline & Total & 26 & & 1 & 30 \\
\hline
\end{tabular}

Sumber: Analisis data, 2021 
Hasil overlay zona kerentanan dengan permukiman, menunjukkan daerah kondisi terpadat penduduk seperti di Desa Sumbersari termasuk zona kerentanan tinggi, seperti yang sajikan pada Gambar 5 . Kerentanan airtanah terhadap pencemaran agak tinggi memiliki sifat tercemar sebagian atau hingga 50\% oleh sumber pencemar (polutan), hal tersebut dapat berlangsung secara berulang (Elsayed et al., 2020; Putranto dkk, 2020). Kerentanan airtanah terhadap pencemaran tinggi memiliki perluang terjadinya pencemaran oleh semua polutan dengan intensitas yang tinggi, dalam jangka waktu yang lama dan waktu relatif cepat.

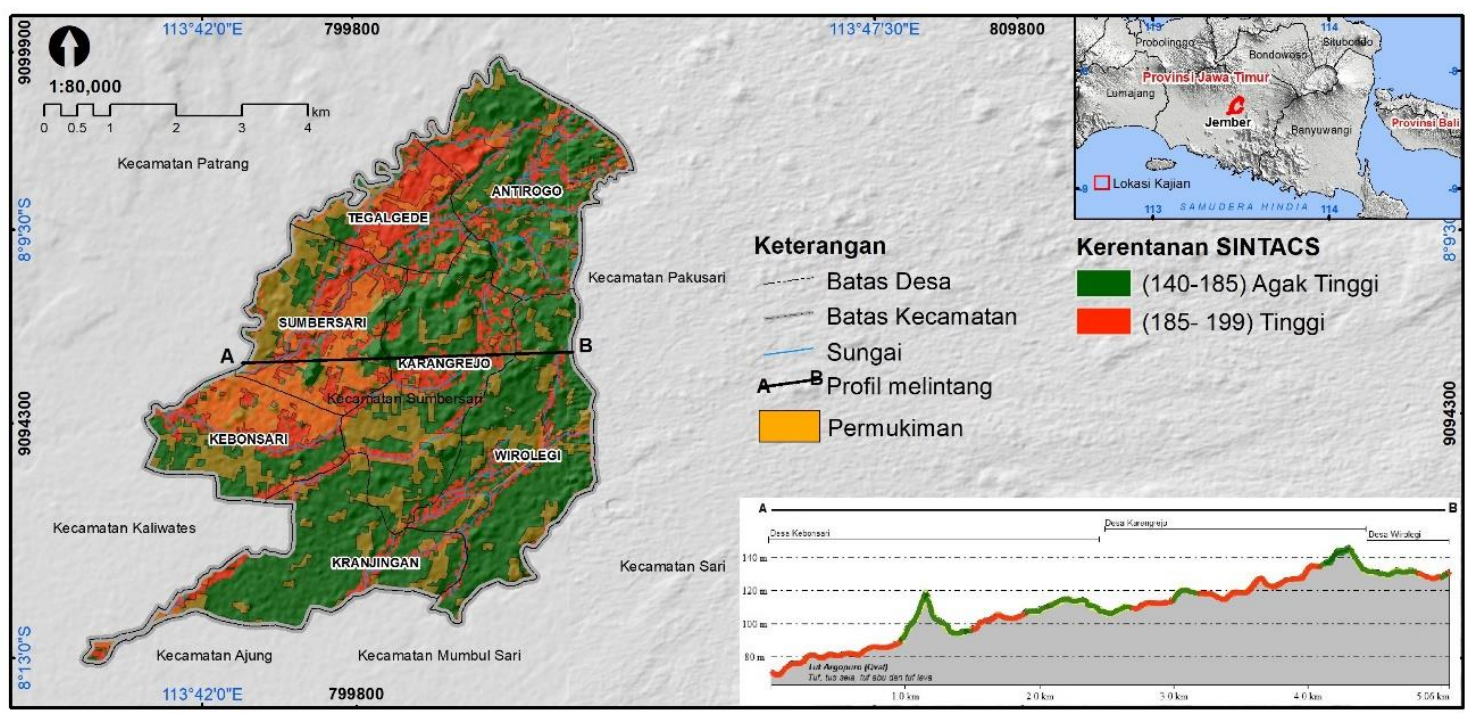

Gambar 5. Tingkat kerentanan agak tinggi dan tinggi terhadap pencemaran di Kota Jember

Kerentanan agak tinggi memiliki karaktersistik zona tersebut dapat terjadi pencemaran hingga 50\% sumber pencemar (polutan) yang dibuang secara terus menerus atau berulang (Hipsey et al., 2020). Saran yang dapat diberikan adalah dengan pemantauan berkala tentang kuantitas dan pemantuan kualitas dari sampel air yang didasarkan atas standar baku mutu air minum dan pengelolaan limbah terpadu. Sedangkan kerentanan tinggi mempunyai kerentanan terjadi pencemaran setengah lebih atau hingga $75 \%$ dari sumber pencemar (polutan) yang berlangsun berulang dengan waktu pencemaran relatif cepat
(Febriarta, dkk, 2020). Saran yang dapat diberikan adalah dengan pembuatan sumur sampel untuk uji pemantauan kuantitas dan kualitas airtanah, edukasi dan pengenalan informasi tentang pengelolaan limbah, terutama limbah domestik, pembuatan sanitasi yang terintegrasi dengan saluran ipal air limbah, dan untuk kerentanan yang sangat tinggi diperlukan pembuatan peraturan daerah tentang pengelolaan sampah dan limbah industri terpadu.

\section{Penutup}

Hasil penelitian multi kriteria sifat hidrogeologi menghasilkan tingkat 
kerentanan airtanah menjadi dua (2) kelas. Nilai indek kerenatanan SINTACS diperoleh tingkat kerentanan agak tinggi (140-185) dan tinggi dengan nilai indek (186-199). Faktor yang dominan mempengaruhi tingkat kerentanan antara lain Kedalaman freatik dan kondisi aerasi (zona Tak Jenuh). Penilaian dengan metode SINTACS menghasilkan nilai indek dengan rentang yang relatif panjang sehingga dapat diketahui parameter yang paling dominan dalam kerentanan, yaitu kedalaman muka airtanah dan tekstur tanah. Metode SINTAC dapat merepresntasikan kerentanan secara keruangan (spasial) dengan skala kecil. Dalam perhitungan dengan metode SINTACS diperlukan ketersediaan data yang relatif banyak sehingga menjadi kendala dalam pemodelan kerentanan airtanah terhadap pencemaran.

\section{Ucapan Terima Kasih}

Ucapan terima kasih ditujukan kepada Badan Perencanaan dan Pembangunan Daerah (BAPPEDA) Kabupaten Jember, yang telah memfasilitasi dan mendukung penelitian ini.

\section{Daftar Pustaka}

Anim-Gyampo, M., Anornu, G. K., Appiah-Adjei, E. K., \& Agodzo, S. K. (2019). Quality and health risk assessment of shallow groundwater aquifers within the Atankwidi basin of Ghana. Groundwater for Sustainable Development, 9, 100217. https://doi.org/10.1016/j.gsd.2019. 100217

Anzaldua, G., Gerner, N. V., Lago, M. Abhold, K., Hinzmann, M., Beyer,
S., Winking, C., Riegels, N., Krogsgaard Jensen, J., Termes, M., Amorós, J., Wencki, K., Strehl, C., Ugarelli, R., Hasenheit, M. Nafo, I., Hernandez, M., Vilanova, E., Damman, S., ... Birk, S. (2018). Getting into the water with the Ecosystem Services Approach: The DESSIN ESS evaluation framework. Ecosystem Services, 30, 318-326. https://doi.org/10.1016/j.ecoser.20 17.12 .004

Asdak, C. (2002). Hidrologi dan Pengelolaan Daerah Aliran Sungai. Gadjah Mada University Press.

Bastani, M., \& Harter, T. (2020). Effects of upscaling temporal resolution of groundwater flow and transport boundary conditions on the performance of nitrate-transport models at the regional management scale. Hydrogeology Journal, 28(4), 1299-1322. https://doi.org/10.1007/s10040020-02133-x

BIG. (2018). DEMNAS 2314-441 dan DEMNAS2314-423. Badan Informasi Geospasial (BIG).

BSN. (2002). Standar Nasional Indonesia No. 19-6728.1-2002 Penyusunan Neraca Sumber Daya - Bagian 1: Sumber Daya Air Spasial. Badan Standardisasi Nasional. In Badan Standardisasi Nasional (BSN): Vol. ICS 13.060. Badan Standardisasi Nasional (BSN).

BSN. (2005). Standar Nasional Indonesia (SNI) no.13-1712-2005 tentang penyelidikan potensi air tanah skala 1:100.000 atau lebih besar. Badan Standardisasi Nasional (BSN).

Civita, M. (1994). La carte della vulnerabilita 'degli acquiferi all'inquiamento: Teoria e Pratica. Pitagora editrice.

Civita, M., \& De Maio, M. (2004). 
Assessing and mapping Groundwater Vulnerability to Contamination: The Italian "Combined Approach. Geofisica Internacional, 2(1), 14-28.

Elsayed Gabr, M., Soussa, H., \& Fattouh, E. (2020). Groundwater quality evaluation for drinking and irrigation uses in Dayrout city Upper Egypt. Ain Shams Engineering Journal. https://doi.org/10.1016/j.asej.2020. 05.010

Febriarta, E., \& Wibowo, Y. A. (2021) Kerentanan Gerakan Tanah Menggunakan Teknik Geospasial Statistik di Macang Pacar, Nusa Tenggara Timur. Jurnal Geografi. 18(1). 9-20. https://doi.org/10.15294/jg.v18i1

Febriarta, E., \& Larasati, A. (2020). Karakteristik Akuifer Air Tanah Dangkal Di Endapan Muda Merapi Yogyakarta. Jurnal Sains Dan Teknologi Lingkungan, 12(2), 8499.

https://doi.org/https://doi.org/10.20 885/jstl.vol12.iss2.art1

Febriarta, E., Marfai, M. A., Hizbaron, D. R., \& Larasati, A. (2020). Kajian Spasial Multi Kriteria DRASTIC Kerentanan Air tanah Pesisir Akuifer Batugamping di Tanjungbumi Madura. Jurnal IImu Lingkungan, 18(3), 476-487. https://doi.org/10.14710/jil.18.3.47 6-487

Febriarta, E., Oktama, R., \& Purnama, S. (2020). Analisis Daya Dukung Lingkungan Berbasis Jasa Ekosistem Penyediaan Pangan dan Air Bersih di Kabupaten Semarang. Geomedia: Majalah IImiah Dan Informasi Kegeografian, 18(1), 12-24. https://doi.org/10.21831/gm.v18i1. 30612

Febriarta, E., \& Riasasi, W. (2019). Karakteristik Kualitas Air Embung Tambakboyo Di Kabupaten
Sleman Yogyakarta. Seminar Nasional Pengelolaan Pesisir Dan Daerah Aliran Sungai Ke-5, 5, 117-123.

Febriarta, E., \& Widyastuti, M. (2020). Kajian Kualitas Air Tanah Dampak Intrusi Di Sebagian Pesisir Kabupaten Tuban. Jurnal Geografi: Media Informasi Pengembangan Dan Profesi Kegeografian, 17(2), 39-48. https://doi.org/10.15294/jg.v17i2.2 4143

Fetter, C. W. (2004). Applied Hydrogeology (5th ed.). Merril Publishing Company.

Gunawan, W. A. ., Sisinggih, D., \& Dermawan, V. (2013). Studi Kerentanan Airtanah Terhadap Kontaminan Di Cekungan Airtanah Negara Kabupaten Jembrana. Jurnal Pengariran, 4(2), 1-10.

Hipsey, M. R., Gal, G., Arhonditsis, G. B., Carey, C. C., Elliott, J. A., Frassl, M. A., Janse, J. H., de Mora, L., \& Robson, B. J. (2020). A system of metrics for the assessment and improvement of aquatic ecosystem models. Environmental Modelling \& Software, 128, 104697. https://doi.org/10.1016/j.envsoft.20 20.104697

KESDM. (2015a). Litologi Akuifer. Kementerian Energi dan Sumber Daya Mineral.

KESDM. (2015b). Produktivitas Akuifer. Kementerian Energi dan Sumber Daya Mineral.

KESDM. (2018). Cekungan Air Tanah (CAT). Kementerian Energi dan Sumber Daya Mineral.

Li, R., Yin, Z., Wang, Y., Li, X., Liu, Q. \& Gao, M. (2018). Geological resources and environmental carrying capacity evaluation review, theory, and practice in China. China Geology, 1(4), 556565.

https://doi.org/10.31035/cg201805 
0

Linggasari, S., Cahyadi, T. ., \& Ernawati, R. (2019). Overview Metode Perhitungan Kerentanan Airtanah Terhadap Rencana Penambangan. Prosiding Nasional Rekayasa Teknologi Industri Dan Informasi XIV Tahun 2019 (ReTII)., 14, 123-129.

MEA. (2005). Ecosystems and Human Well- Being: Synthesis. Island Press.

Mepaiyeda, S., Madi, K., Gwavava, O., \& Baiyegunhi, C. (2020). Geological and geophysical assessment of groundwater contamination at the Roundhill landfill site, Berlin, Eastern Cape, South Africa. Heliyon, 6(7), e04249.

https://doi.org/10.1016/j.heliyon.20 20.e04249

Priyono, P., \& Rizal, N. S. (2013). Kajian Potensi Air Tanah Dengan Metode Geolistrik Sebagai Antisipasi Kelangkaan Air Bersih Wilayah Perkotaan. Jurnal Elevasi, 4(18), 1-8.

Purnama, S., \& Cahyadi, A. (2019). Groundwater Vulnerability to Pollution in Kasihan District, Bantul Regency, Indonesia. Forum Geografi, 33(2), 140-152. https://doi.org/10.23917/forgeo.v33 i2.7672

Purnama, S., Cahyadi, A., Febriarta, E., Khakhim, N., \& Prihatno, $\mathrm{H}$. (2013). Identifikasi Airtanah Asin Berdasarkan Pendugaan Geolistrik Di Pesisir Kota Cilacap Jawa Tengah. Geomedia: Majalah IImiah Dan Informasi Kegeografian, 11(2), 183-190. https://doi.org/10.21831/gm.v11i2. 3450

Putranto, T. T. (2019). Studi Kerentanan Airtanah Terhadap Pencemaran Dengan Menggunakan Metode Drastic Pada Cekungan Airtanah (Cat)
Karanganyar-Boyolali, Provinsi Jawa Tengah. Jurnal IImu Lingkungan, 17(1), 159. https://doi.org/10.14710/jil.17.1.15 9-171

Putranto, T. T., \& Rüde, T. (2016). Hydrogeological Model of an Urban City in a Coastal Area, Case study: Semarang, Indonesia. Indonesian Journal on Geoscience, 3(1). https://doi.org/10.17014/ijog.3.1.17 $-27$

Putranto, T. T., Winarno, T., \& Susanta, A. P. A. (2020). Risk Assessment of Groundwater Abstraction Vulnerability Using Spatial Analysis: Case Study at Salatiga Groundwater Basin, Indonesia. Indonesian Journal on Geoscience, $\quad$ 7(2). https://doi.org/10.17014/ijog.7.2.21 5-224

RI. (2017). Peraturan Menteri Energi dan Sumber daya Mineral No.2 Tahun 2017 tentang Cekungan Air Tanah di Indonesia. Menteri Energi dan Sumber Daya Mineral.

Sapei, T., Suganda, H., Astadiredja, K. A. S., \& Suharsono. (1992). Peta Geologi Lembar Jember. Pusat Penelitian dan Pengembangan Geologi.

Singhal, B. B. S., \& Gupta, R. P. (2010). Applied Hydogeology of Fracture Rock. Springer Dordrecht Heidelberg London.

Sisultan. (2017). Peta Tanah Skala 1:50.000. Kementerian Pertanian.

Sugianti, K., Mulyadi, D., \& Maria, R. (2016). Analisis kerentanan pencemaran air tanah dengan pendekatan DRASTIC di Bandung Selatan. Jurnal Lingkungan Dan Bencana Geologi, 7(1), 19-33. https://doi.org/http://dx.doi.org/10.3 4126/jlbg.v7i1.91

Thapa, R, Gupta, S., Guin, S., \& Kaur, H. (2018). Sensitivity analysis and mapping the potential groundwater 
vurnerability zones in Birbhum district, India: A comparative approach between vurnerability models. Water Science, 32, 4466.

Thapa, Raju, Gupta, S., Kaur, H., \& Baski, R. (2019). Assessment of groundwater quality scenario in respect of fluoride and nitrate contamination in and around Gharbar village, Jharkhand, India. HydroResearch, 2, 60-68. https://doi.org/10.1016/j.hydres.20 19.09.002

Todd, D. K., \& Mays, L. W. (2005). Groundwater Hydrology (3rd ed.). John Wiley \& Sons, Inc.

Vienastra, S., \& Febriarta, E. (2020). Penentuan Zona Kerentanan Airtanah Metode Simple Vertical Vulnerability Di Pulau Yeben. JURNAL SWARNABHUMI: Jurnal Geografi Dan Pembelajaran Geografi, $\quad 5(2), \quad 58$. https://doi.org/10.31851/swarnabh umi.v5i2.4431

Vrba, J., \& Zaporozec, A. (1994). Guidebook on Mapping Groundwater Vulnerability. International Association of Hydrogeologist.

Wicaksono, A. P., Febriarta, E., Nurani, D. T. T., \& Larasati, A. (2020). Evaluasi Kebutuhan Air Persemaian Di Kawasan Karst Nggorang Manggarai Barat, Labuan Bajo, Nusa Tenggara Timur. Jurnal IImu Lingkungan, 18(3), 572-581.

https://doi.org/10.14710/jil.18.3.57 $2-581$

Widodo, B., Lupyanto, R., Sulistiono, B., Harjito, D. A., Hamidin, J., Hapsari, E., Yasin, M., \& Ellinda, C. (2015). Analysis of Environmental Carrying Capacity for the Development of Sustainable Settlement in Yogyakarta Urban Area. Procedia Environmental Sciences,
28(SustaiN 2014), 519-527. https://doi.org/10.1016/j.proenv.20 15.07.062 